$\frac{\text { DE }}{\text { DE GRUYTER }}$ OPEN

\title{
EFFECT OF CAPONIZATION ON MEAT QUALITY OF GREENLEG PARTRIDGE COCKERELS*
}

\author{
Jolanta Calik $^{1 \star}$, Katarzyna Połtowicz ${ }^{2}$, Sylwester Świątkiewicz ${ }^{3}$, Józefa Krawczyk ${ }^{1}$, Joanna Nowak ${ }^{2}$ \\ ${ }^{1}$ Department of Animal Genetic Resources Conservation, \\ ${ }^{2}$ Department of Animal Genetics and Breeding, \\ ${ }^{3}$ Department of Animal Nutrition and Feed Science, \\ National Research Institute of Animal Production, 32-083 Balice n. Kraków, Poland \\ •Corresponding author: jolanta.calik@izoo.krakow.pl
}

\begin{abstract}
The objective of the study was to determine the effect of caponizing Greenleg Partridge cockerels on slaughter parameters and meat quality. In total 80 Greenleg Partridge cockerels were assigned to two groups with 40 birds per group. Group I (control) consisted of uncastrated cockerels and group II contained birds that were castrated at 8 weeks of age. Birds were kept until 24 weeks of age and fed the same diet ad libitum. Body weight was recorded at 1, 8, 16 and 24 weeks of age. Dressing percentage, proportion of breast and leg muscles, giblets and abdominal fat, and microstructure of the pectoralis superficialis muscle were determined postmortem. Physicochemical characteristics of meat $\left(\mathrm{pH}, \mathrm{CIE} \mathrm{L}^{*} \mathrm{a} * \mathrm{~b} *\right.$ colour, water holding capacity, drip loss, thawing loss, cooking loss, shear force, texture parameters and chemical composition) were determined and sensory evaluation was performed. The castration of Greenleg Partridge cockerels contributed to increases in body weight, dressing percentage, and carcass muscle and fat content, and changed the colour of bird skin and muscles. The leg muscles of capons were characterized by higher $\mathbf{p H}_{24 \mathrm{~h}}$, better water holding capacity, a tendency for higher fat concentration, and better sensory quality. The breast muscles of castrated cockerels lost more water and were tougher than the same muscles from uncastrated cockerels, but received better scores for flavour. In conclusion, the results of this study indicate that the caponized Greenleg Partridge cockerels can be used as a valuable material for production of high quality meat.
\end{abstract}

Key words: caponization, males, native breed, growth performance, meat quality

The caponization of poultry is an old practice that was used long before Christ in China, Rome and Greece. It was first associated with a religious ritual but later the procedure was performed to increase the body weight of cockerels and to improve the quality of their meat (Calik, 2014).

\footnotetext{
*This study was financed from statutory activity, project no 03-004.01.
} 
Today, cockerels are caponized on a wider scale in Italy, France, Taiwan, China and the USA, where they are marketed as high quality products (Sirri et al., 2009). Surgical castration is most often performed (Symeon et al., 2010). Immunocastration, where female sex hormones are used to suppress testosterone, is also used in the USA (Rahman et al., 2004). However, research shows that the meat from surgically castrated cockerels is of better quality. According to the Commission Regulation No $543 / 2008$ of 16 June 2008, "a capon is a male fowl castrated surgically before reaching sexual maturity and slaughtered at a minimum age of 140 days". Most capons are produced from local breeds of slow-growing poultry. In Spain, France or Hungary, this industry contributes to the conservation of chicken genetic resources (Muriel Duran, 2004).

Castration may cause changes in the appearance of the cockerels, including degeneration of the comb and wattle, and behavioural changes (Chen et al., 2006). Compared to intact cockerels, capons have better metabolism and reach higher body weights, and their meat is more delicate and juicy (Tor et al., 2002; 2005). Furthermore, greater adipose tissue accumulation has a beneficial effect on improving taste properties and this is of prime importance to consumers, who are increasingly demanding better tasting products (Shao et al., 2009; Sirri et al., 2009; Sinanoglou et al., 2011). At the same time, certain groups of consumers want products with specific quality attributes, which distinguish themselves from conventional poultry products.

The current programme for livestock genetic resources conservation in Poland covers 19 lines of laying hens, among which the old native breed of Greenleg Partridge attracts special interest. Best suited to backyard and free range conditions, the breed is used mainly for egg laying (Krawczyk et al., 2011). With egg production becoming more intensive, there is an increasing number of redundant cockerels, which form $50 \%$ of hatched chicks. This problem may be solved by using these birds for capon production, especially as this breed distinguishes itself from the other conserved lines with favourable sensory attributes and desirable physicochemical properties of the meat (Połtowicz et al., 2004). Therefore, the objective of this study was to determine the effect of caponization of Greenleg Partridge cockerels on slaughter parameters and meat quality.

\section{Material and methods}

The experiment was carried out with 80 Greenleg Partridge cockerels, which were weighed, individually tagged, and randomly assigned to two groups with 40 birds per group. Group I (control) consisted of uncastrated cockerels and group II contained birds that were castrated at 8 weeks of age. Eight-week-old birds weighing around $440 \mathrm{~g}$ were caponized under general anaesthesia by a veterinary surgeon. Throughout the rearing period (until week 24), all the birds were fed the same compound feeds ad libitum (Table 1) and kept on litter under optimum environmental conditions at a stocking density of $7 \mathrm{birds} / \mathrm{m}^{2}$. 
Table 1. Composition of the diets used in the experiment $(\mathrm{kg} / 100 \mathrm{~kg})$

\begin{tabular}{l|c|c|c}
\hline \multicolumn{1}{c|}{ Component } & $\begin{array}{c}\text { Diet I } \\
\text { day 1 to week 7 }\end{array}$ & $\begin{array}{c}\text { Diet II } \\
\text { weeks 8 to 16 }\end{array}$ & $\begin{array}{c}\text { Diet III } \\
\text { weeks 17 to 24 }\end{array}$ \\
\hline Ground maize & 41.35 & 40.45 & 35.70 \\
Ground wheat & 25.00 & 22.00 & 29.00 \\
Ground triticale & - & 5.00 & 7.00 \\
Ground barley & - & 5.00 & 7.00 \\
Soybean meal & 30.00 & 24.00 & 18.00 \\
Ground limestone & 1.25 & 1.30 & 1.20 \\
Dicalcium phosphate & 1.60 & 1.45 & 1.30 \\
NaCl & 0.30 & 0.30 & 0.30 \\
Vitamin-mineral premix DKA-F (finisher) & 0.50 & 0.50 & 0.50 \\
(0.5\%) (kg) & & & \\
Crude protein (g) & 204 & 184 & 165 \\
Metabolizable energy (MJ) & 11.92 & 12.05 & 12.18 \\
& 2850 & 2880 & 2910 \\
Lys (g) & 10.3 & 8.90 & 7.50 \\
Met (g) & 3.10 & 2.85 & 2.60 \\
Ca (g) & 8.95 & 8.60 & 7.90 \\
P available (g) & 4.10 & 3.80 & 3.50 \\
\hline
\end{tabular}

Cockerels were weighed at 1, 8, 16 and 24 weeks of age. At the end of the rearing period, 8 birds whose body weights were similar to the group average were selected from each group for slaughter. Prior to the slaughter, birds were subjected to a 12-hour feed withdrawal but had constant access to water. Castration success (removal of the testes) was determined post-slaughter. Immediately after the slaughter, samples were collected from the pectoralis superficialis muscle for histological examination. Samples were frozen in liquid nitrogen and freezer stored $\left(-86^{\circ} \mathrm{C}\right)$ until analysis. A CyberScan $10 \mathrm{pH}$ meter (Singapore) was used to determine the $\mathrm{pH}_{15 \min }$ of breast and leg muscles, which was followed by standard post-slaughter processing (scalding, defeathering, evisceration). The carcasses (with neck and giblets) were placed in a cold store at $4^{\circ} \mathrm{C}$. After 24 hours, the carcasses were analysed for CIE L*a*b* colour (Minolta CR 310, Japan) and again for acidity of breast and leg muscles $\left(\mathrm{pH}_{24 \mathrm{~h}}\right)$. Chilled carcasses were subjected to simple carcass analysis according to the method described by Ziołecki and Doruchowski (1989), and the dissected muscles were evaluated for selected technological parameters. CIE L*a*b* colour of the muscles was determined with a Minolta CR310 chroma meter (Japan) using illuminant $\mathrm{C}$ as a light source. Colour measures were performed on the inner surface of the left breast muscle (pectoralis superficialis) and the left thigh muscles immediately after deboning. When selecting the surfaces for the analysis we made sure there were no discolorations, visible blood vessels and defects that could affect the readings. Breast muscle colour was expressed in terms of CIE values for lightness ( $\left.\mathrm{L}^{*}\right)$, redness $\left(a^{*}\right)$ and yellowness $\left(b^{*}\right)$. Water holding capacity (WHC) of the muscles was determined based on the volume of free water squeezed from a ground meat sample using the filter paper method (Grau and Hamm, 1953). Drip loss was determined $48 \mathrm{~h}$ postmortem based on percent loss of muscle mass during 24-hour storage of 
the meat at $4^{\circ} \mathrm{C}$. Thawing loss was determined from meat weight loss after 21-day storage at $-18^{\circ} \mathrm{C}$. Cooking loss was determined from percent loss of meat weight as a result of cooking in a water bath at $100^{\circ} \mathrm{C}$ until a core temperature of $78^{\circ} \mathrm{C}$ was obtained in the thickest part of the sample. After cooling and weighing for cooking loss determination, samples were prepared for the shear force and texture measurements. From the thickest upper part of cooked and chilled pectoralis superficialis muscle, two cylindrical pieces $(1.27 \mathrm{~cm}$ in diameter and 3 and $1.5 \mathrm{~cm}$ in length) were cut for analysis of shear force and texture, respectively. Both tests were performed using an Instron 5542 machine (UK). Shear force (N) was determined based on measurement of the maximum force needed to shear the sample with a triangular Warner-Bratzler attachment. The cylindrical piece was cut at three points perpendicular to the orientation of the muscle fibres and the mean was calculated. Texture analysis of toughness $(\mathrm{N})$, springiness $(\mathrm{mm})$, cohesiveness, gumminess $(\mathrm{N})$ and chewiness $(\mathrm{mJ})$ was performed using a compression attachment of $50 \mathrm{~mm}$ diameter and Texture Profile Analysis (TPA) test. Each sample was subjected to a double compression test with $60 \%$ deformation, perpendicular to the muscle fibre orientation. Crosshead speed was $200 \mathrm{~mm} / \mathrm{min}$. with an interval of $2 \mathrm{~s}$ and detection threshold of $0.01 \mathrm{~N}$.

The breast and leg muscles were subjected to sensory assessment according to the methodology developed by Baryłko-Pikielna and Matuszewska (2009). The assessment was made by a panel of 8 adult individuals based on a scale of 1 to 5 , with the best score being 5 and the worst score being 1. For each parameter, the scores were accurate to 0.5 point. Aroma, juiciness, tenderness and flavour were assessed.

In addition, samples of breast and leg muscles were collected from 5 cockerels and 5 capons subjected to slaughter analysis in order to determine the chemical composition of water (dry matter) by the drying method (PN-ISO1442: 2000); crude protein according to Kjeldahl and using the nitrogen to protein conversion factor of 6.25 (PN-75/A-04018/Az3:2002); crude fat using the Soxhlet method (Buchi 810) according to PN-ISO 1444:2000; crude ash (PN-ISO 936:2000); and cholesterol using the colorimetric method (PO26 ver. 1: 2001).

The collected samples, which were stored at $-86^{\circ} \mathrm{C}$, were used to measure muscle fibre diameter. Samples were cut in a cryostat (Slee MEV, Germany) into $10 \mu \mathrm{m}$ thick pieces at $-25^{\circ} \mathrm{C}$ and stained by hematoxylin and eosin. Next, sections were dehydrated in a graded series of ethyl alcohol, cleared in xylene and mounted in DPX mounting medium (Fluka, Buchs, Switzerland). A minimum of 200 fibres were counted in each section using a NIKON E600 light microscope. The diameter of muscle fibre was quantified with an image analysis system using Multi Scan v. 14.02 computer program.

The results were statistically analysed by one-way analysis of variance (ANOVA). The calculations were made using Statgraphics plus 5.1 package.

\section{Results}

Before the onset of the study, the body weight of cockerels from groups I and II was similar and averaged $38.2 \mathrm{~g}$ on day 1 of age and $444 \mathrm{~g}$ at 8 weeks of age when 
the birds were castrated (Table 2). At the end of fattening at 24 weeks, the body weight of cockerels and capons differed and was significantly higher (by $240 \mathrm{~g}$ ) in the latter. Group II was also characterized by significantly higher dressing percentage with and without giblets (by 1.41 and 1.8 percentage points, respectively) and lower carcass chilling losses (Table 3 ). Capons had a significantly higher content of breast muscle (by 1.22 percentage points) and leg muscle (by 1.47 percentage points) in the carcass. In group II, there was also a higher proportion of giblets, but these differences were confirmed statistically only for gizzard. No significant differences were noted for the proportion of bones, the content of which tended to be higher in the carcasses of cockerels. Intact cockerels and capons differed significantly in the content of abdominal fat, which constituted $2.59 \%$ and $4.95 \%$ of carcass weight, respectively $(\mathrm{P} \leq 0.01)$. The birds from both groups also differed in skin colour. Compared to the carcasses of intact cockerels, the carcasses of capons were more yellow $(\mathrm{P} \leq 0.05)$.

Table 2. Effect of caponization on body weight of birds (g)

\begin{tabular}{lcc}
\hline \multicolumn{1}{c|}{ Item } & $\begin{array}{c}\text { Group I } \\
\text { (Uncastrated cockerels) }\end{array}$ & $\begin{array}{c}\text { Group II } \\
\text { (Capons) }\end{array}$ \\
\hline 1 day of age & $38.28 \pm 3.28$ & $38.06 \pm 2.62$ \\
8 weeks of age (before castration) & $439.30 \pm 54.85$ & $448.92 \pm 66.06$ \\
16 weeks of age & $1471.06 \mathrm{a} \pm 182.13$ & $1608.50 \mathrm{~b} \pm 157.02$ \\
24 weeks of age & $2045.44 \mathrm{~A} \pm 137.18$ & $2285.87 \mathrm{~B} \pm 151.311$ \\
\hline
\end{tabular}

$\mathrm{a}, \mathrm{b}-$ values in rows with different letters differ significantly $(\mathrm{P} \leq 0.05)$.

$\mathrm{A}, \mathrm{B}-$ as above for $\mathrm{P} \leq 0.01$.

Table 3. Effect of caponization on quality of the carcass

\begin{tabular}{lcr}
\hline \multicolumn{1}{c}{ Item } & $\begin{array}{c}\text { Group I } \\
\text { (Uncastrated cockerels) }\end{array}$ & \multicolumn{1}{c}{$\begin{array}{r}\text { Group II } \\
\text { (Capons) }\end{array}$} \\
\hline Carcass weight loss during chilling (\%) & $1.92 \pm 0.31$ & $1.75 \pm 0.30$ \\
Dressing percentage with giblets & $71.66 \mathrm{a} \pm 1.08$ & $73.07 \mathrm{~b} \pm 0.98$ \\
Dressing percentage without giblets & $67.37 \mathrm{a} \pm 1.28$ & $69.17 \mathrm{~b} \pm 1.41$ \\
Breast muscles (\%) & $16.06 \mathrm{a} \pm 0.63$ & $17.28 \mathrm{~b} \pm 0.40$ \\
Leg muscles (\%) & $20.34 \mathrm{a} \pm 0.51$ & $21.81 \mathrm{~b} \pm 0.73$ \\
Giblets (\%): & $5.20 \pm 0.342$ & $5.53 \pm 0.26$ \\
liver (\%) & $2.32 \pm 0.14$ & $2.39 \pm 0.20$ \\
gizzard (\%) & $2.29 \mathrm{a} \pm 0.33$ & $2.56 \mathrm{~b} \pm 0.29$ \\
heart (\%) & $0.59 \pm 0.04$ & $0.58 \pm 0.05$ \\
Leg bones (\%) & $5.29 \pm 0.56$ & $5.04 \pm 0.44$ \\
Abdominal fat (\%) & $2.59 \mathrm{~A} \pm 0.68$ & $4.95 \mathrm{~B} \pm 1.29$ \\
Carcass colour: & & \\
L* & $69.93 \pm 0.81$ & $71.01 \pm 1.15$ \\
a* & $2.58 \pm 0.66$ & $2.10 \pm 0.36$ \\
b* & $11.28 \mathrm{a} \pm 1.65$ & $12.77 \mathrm{~b} \pm 0.82$ \\
\hline
\end{tabular}

For explanations, see Table 2.

The measurements of muscle fibre diameter and the technological parameters of breast and leg muscles are shown in Table 4. They show a significant effect of the castration procedure on the microstructure of the pectoralis superficialis muscle. 
Compared to the control group, breast muscles from capons were characterized by smaller fibre diameter and the difference was statistically significant $(\mathrm{P} \leq 0.01)$.

Table 4. Effect of caponization on muscle fibre diameter and technological parameters of the meat

\begin{tabular}{|c|c|c|c|c|}
\hline \multirow{2}{*}{ Item } & \multicolumn{2}{|c|}{ Breast muscles } & \multicolumn{2}{|c|}{ Leg muscles } \\
\hline & $\begin{array}{c}\text { Group I } \\
\text { (Uncastrated cockerels) }\end{array}$ & $\begin{array}{l}\text { Group II } \\
\text { (Capons) }\end{array}$ & $\begin{array}{c}\text { Group I } \\
\text { (Uncastrated cockerels) }\end{array}$ & $\begin{array}{l}\text { Group II } \\
\text { (Capons) }\end{array}$ \\
\hline Fibre diameter $(\mu \mathrm{m})$ & $51.05 \mathrm{~A} \pm 2.13$ & $45.94 \mathrm{~B} \pm 1.62$ & - & - \\
\hline $\mathrm{pH}_{15 \min }$ & $6.29 \pm 0.11$ & $6.37 \pm 0.11$ & $6.57 \pm 0.12$ & $6.59 \pm 0.11$ \\
\hline $\mathrm{pH}_{24 \mathrm{~h}}$ & $5.75 \pm 0.09$ & $5.79 \pm 0.08$ & $5.93 \mathrm{~A} \pm 0.08$ & $6.16 \mathrm{~B} \pm 0.11$ \\
\hline $\mathrm{L}^{*}$ & $53.84 \pm 2.23$ & $55.44 \pm 1.98$ & $35.27 \mathrm{a} \pm 1.29$ & $37.11 \mathrm{~b} \pm 1.88$ \\
\hline$a^{*}$ & $10.80 \mathrm{a} \pm 1.05$ & $9.46 \mathrm{~b} \pm 0.86$ & $18.14 \pm 0.92$ & $17.77 \pm 1.20$ \\
\hline $\mathrm{b}^{*}$ & $6.59 \mathrm{~A} \pm 1.06$ & $9.13 \mathrm{~B} \pm 1.40$ & $4.79 \mathrm{~A} \pm 0.48$ & $5.99 \mathrm{~B} \pm 0.74$ \\
\hline WHC (\%) & $17.01 \pm 3.72$ & $16.68 \pm 3.31$ & $19.04 \pm 3.21$ & $17.42 \pm 1.70$ \\
\hline Drip loss (\%) & $0.55 \pm 0.10$ & $0.54 \pm 0.17$ & $0.38 \pm 0.06$ & $0.41 \pm 0.08$ \\
\hline Thawing loss (\%) & $1.45 \pm 0.51$ & $1.67 \pm 0.93$ & $0.70 \pm 0.15$ & $0.52 \pm 0.28$ \\
\hline Cooking loss (\%) & $14.16 \mathrm{~A} \pm 1.50$ & $16.11 \mathrm{~B} \pm 0.88$ & $20.19 \pm 1.32$ & $19.18 \pm 2.65$ \\
\hline Total loss $(\%)$ & $15.86 \mathrm{a} \pm 1.84$ & $18.06 \mathrm{~b} \pm 1.14$ & $21.05 \pm 1.27$ & $20.05 \pm 2.66$ \\
\hline Shear force $(\mathrm{N})$ & $14.61 \pm 2.63$ & $15.50 \pm 2.87$ & - & - \\
\hline Toughness (N) & $7.69 \mathrm{~A} \pm 1.35$ & $10.31 \mathrm{~B} \pm 2.12$ & - & - \\
\hline Springiness (mm) & $7.32 \pm 0.08$ & $7.32 \pm 0.08$ & - & - \\
\hline Cohesiveness & $0.53 \pm 0.06$ & $0.52 \pm 0.02$ & - & - \\
\hline Gumminess (N) & $4.13 \pm 1.06$ & $5.34 \pm 1.20$ & - & - \\
\hline Chewiness (mJ) & $30.41 \pm 7.98$ & $39.34 \pm 9.00$ & - & - \\
\hline
\end{tabular}

For explanations, see Table 2.

The breast muscles from both groups of birds also differed in some physicochemical parameters. The higher $\mathrm{L}^{*}$ and $\mathrm{b}^{*}$ values $(\mathrm{P} \leq 0.01)$ in group II are indicative that capon breast muscles were lighter and significantly more yellow. The breast muscles of cockerels (group I) were more red $(\mathrm{P} \leq 0.05)$. Similar relationships were observed for the colour of leg muscles, which were lighter $(\mathrm{P} \leq 0.05)$ and more yellow in capons $(\mathrm{P} \leq 0.01)$, and showed a tendency for higher redness in cockerels.

The breast muscles of birds from groups I and II had almost the same $\mathrm{pH}_{24 \mathrm{~h}}$ despite the tendency of capon muscles towards higher $\mathrm{pH}$ measured $15 \mathrm{~min}$. postmortem. At the same time, compared to the muscles of uncastrated cockerels, those from capons were characterized by slightly more favourable water holding capacity and almost the same drip loss. The other parameters, such as thawing loss, cooking loss and total loss of muscle weight due to water loss were more favourable in group I, where muscle yield was 2.2 points higher $(\mathrm{P} \leq 0.05)$ than in group II.

The leg muscles of capons were characterized by significantly higher $\mathrm{pH}_{24 \mathrm{~h}}$ compared to the leg muscles from intact cockerels. At the same time, despite the lack of statistical significance, capon leg muscles showed a strong tendency for better water holding capacity. Most of the parameters of water loss from muscle tissue were lower 
in group II. The leg muscles of capons lost less water both as a result of thawing and cooking, and the differences between the groups were 0.18 and 1.01 percentage points, respectively. Furthermore, the leg muscles of birds from group II were characterized by more favourable WHC value (by 1.62 percentage points).

The caponizing procedure had a significant effect on breast muscle toughness by increasing this parameter by $2.62 \mathrm{~N}(\mathrm{P} \leq 0.01)$. Despite the lack of statistical significance, the breast muscles from both bird groups also differed in shear force (by $0.89 \mathrm{~N}$ ), gumminess (by $1.21 \mathrm{~N}$ ) and chewiness (by $8.93 \mathrm{~mJ}$ ). All these parameters reached higher values in group II. The other texture parameters, such as springiness and cohesiveness were at the same level.

Table 5. Effect of caponization on sensory analysis of the breast and leg muscles

\begin{tabular}{l|c|c|c|c}
\hline \multirow{2}{*}{ Item } & \multicolumn{2}{|c|}{ Breast muscles } & \multicolumn{2}{c}{ Leg muscles } \\
\cline { 2 - 5 } & $\begin{array}{c}\text { Group I } \\
\text { (Uncastrated cockerels) }\end{array}$ & $\begin{array}{c}\text { Group II } \\
\text { (Capons) }\end{array}$ & $\begin{array}{c}\text { Group I } \\
\text { (Uncastrated cockerels) }\end{array}$ & $\begin{array}{r}\text { Group II } \\
\text { (Capons) }\end{array}$ \\
\hline Aroma (pts.) & $4.30 \pm 0.78$ & $4.45 \pm 0.41$ & $4.15 \pm 0.43$ & $4.35 \pm 0.25$ \\
Juiciness (pts.) & $3.95 \pm 0.53$ & $4.35 \pm 0.44$ & $3.75 \mathrm{~A} \pm 0.66$ & $4.55 \mathrm{~B} \pm 0.37$ \\
Tenderness (pts.) & $4.05 \pm 0.51$ & $4.35 \pm 0.47$ & $4.10 \mathrm{a} \pm 0.51$ & $4.60 \mathrm{~b} \pm 0.26$ \\
Flavour (pts.) & $4.00 \mathrm{a} \pm 0.67$ & $4.60 \mathrm{~b} \pm 0.26$ & $4.20 \mathrm{a} \pm 0.63$ & $4.75 \mathrm{~b} \pm 0.46$ \\
\hline
\end{tabular}

For explanations, see Table 2.

In the sensory evaluation (Table 5), both the breast and leg muscles of capons scored higher for all assessment categories, i.e. aroma, juiciness, tenderness, and flavour. It should be noted, however, that statistically significant differences in the sensory quality of breast muscles from the capons and intact cockerels were noted only for flavour, which received a higher score (by 0.60 point) in the former $(\mathrm{P} \leq 0.05)$. In the case of leg muscles, these differences were higher and mostly significant. Compared to uncastrated cockerels, the leg muscles of capons were characterized by significantly better juiciness (3.75 vs. 4.55$)$, tenderness (4.10 vs. 4.60$)$ and flavour (4.20 vs. 4.75).

Table 6. Effect of caponization on chemical analysis of the breast and leg muscles

\begin{tabular}{l|c|r|r|r}
\hline \multirow{2}{*}{\multicolumn{1}{c|}{ Item }} & \multicolumn{2}{c|}{ Breast muscles } & \multicolumn{2}{c}{ Leg muscles } \\
\cline { 2 - 5 } & $\begin{array}{c}\text { Group I } \\
\text { (Uncastrated cockerels) }\end{array}$ & $\begin{array}{c}\text { Group II } \\
\text { (Capons) }\end{array}$ & $\begin{array}{c}\text { Group I } \\
\text { (Uncastrated cockerels) }\end{array}$ & $\begin{array}{r}\text { Group II } \\
\text { (Capons) }\end{array}$ \\
\hline Dry matter (\%) & $26.94 \pm 0.80$ & $26.87 \pm 0.47$ & $26.07 \pm 0.83$ & $27.44 \pm 1.44$ \\
Crude ash (\%) & $1.09 \pm 0.04$ & $1.11 \pm 0.02$ & $1.10 \mathrm{a} \pm 0.04$ & $1.04 \mathrm{~b} \pm 0.03$ \\
Crude protein (\%) & $24.87 \pm 0.30$ & $25.08 \pm 0.21$ & $21.52 \pm 0.47$ & $21.25 \pm 0.34$ \\
Crude fat (\%) & $1.48 \pm 0.30$ & $1.63 \pm 0.33$ & $3.98 \pm 0.56$ & $5.53 \pm 1.41$ \\
Cholesterol (mg/100 g) & $48.53 \pm 2.81$ & $48.67 \pm 1.62$ & $70.55 \pm 3.52$ & $70.81 \pm 2.33$ \\
\hline
\end{tabular}

For explanations, see Table 2.

The present study revealed no significant differences in the content of basic chemical components in the breast muscles of cockerels and capons (Table 6). However, the analysis of the data shows a tendency for slightly higher content of crude 
protein (by 0.21 percentage point), crude fat (by 0.15 percentage point) and cholesterol (by $0.14 \mathrm{mg} / 100 \mathrm{~g}$ ) in the capons. A similar tendency was also noted for the leg muscles, in which the proportion of crude fat and cholesterol in capons was higher by 1.55 and 0.26 percentage points, respectively. In turn, unlike in breast muscles, the leg muscles of capons showed a tendency towards lower crude protein content with a significantly lower crude ash $(\mathrm{P}<0.01)$ and higher dry matter content $(\mathrm{P}>0.05)$.

\section{Discussion}

The present study showed a positive effect of caponization of Greenleg Partridge cockerels on their final body weight, and differences between the groups were already observed from 16 weeks of age. According to Muriel Duran (2004), once the stress of the castration procedure has been overcome, caponization had a positive effect on weight gain. In his study, capons aged 20, 25 and 30 weeks were significantly heavier than their uncastrated contemporaries. According to Mahmud et al. (2013), the higher body weight of caponized cockerels may be associated with a decreased level of androgens. The lower aggression and walking activity of capons contributes to improved feed conversion, which results in both higher weight gain and higher fatness. Likewise, Tor et al. (2002) and Chen et al. (2006) report that caponized birds are characterized by higher body weight gains. In contrast to the above data, Miguel et al. (2008) for Castellana Negra cockerels and Symeon et al. (2010) for broilers did not observe the body weight of castrated cockerels to be higher than that of uncastrated birds. The different growth response of capons may result from the differences in the genetic origin of the birds, caponization age, slaughter age, and the interaction between them.

In our study, castration of cockerels had a positive effect on dressing percentage and carcass quality. Also Muriel Duran (2004) notes the higher dressing percentage, weight and proportion of breast muscle in the carcasses of capons compared to uncaponized cockerels. It may be that, through a lack of sex hormones, castration causes changes in metabolism that lead to earlier development of the breast in capons similar to the growth pattern seen in hens. The improvements in dressing percentage and muscle content of capons were also reported by Tor et al. (2002), Lin and Hsu (2003) and Chen et al. (2007). In another study, however, Chen et al. (2006) found the dressing percentage of capons to be lower than in uncastrated cockerels.

According to some authors, a higher weight of internal organs, especially the liver, gizzard and heart is observed in castrated compared to intact birds (Rahman et al., 2004; Mahmund et al., 2013). Conversely, Lin and Hsu (2003) and Symeon et al. (2010) noted lower heart weight in capons. Our study showed that giblets percentage tended to increase in castrated birds, but the difference was significant only for gizzard. Increased gizzard and liver weight as a result of castration was also reported by Chen et al. (2006) but they found no differences in their percentages.

The bird groups evaluated in our study differed significantly in carcass fatness. Similarly to the studies of Tor et al. (2005), Chen et al. (2006), Sirri et al. (2009), 
Sinanoglou et al. (2011) and Volk et al. (2011), the percentage of abdominal fat was higher in capons. The caponization of cockerels reduces the concentration of testosterone and causes increases in lipogenesis capability and lipid accumulation in the body (Chen et al., 2005). The results of experiment by Chen et al. (2006) indicate that the level of this hormone is negatively correlated to body fatness in birds. In addition, capons consume more feed and due to the lack of fighting behaviour they are less active, which is conducive to deposition of fat (Chen et al., 2006).

In our study, the higher fatness of capons compared to intact cockerels could be a source of the differences in skin colour. Chen et al. $(2006,2007)$ and Rikimaru et al. (2009) report that capons are characterized not only by higher content of abdominal, but also subcutaneous and intramuscular fat. The carotenoids in the feed are accumulated in depot fat and can influence skin colour. In line with the study by Lin and Hsu (2003), the carcasses of our capons showed higher $L^{*}$ and $b^{*}$ values and lower $\mathrm{a}^{*}$ values compared to those of intact birds. Also according to Cason et al. (1987), breast skin removed from the carcass of capons had significantly higher lightness (L*) values compared to intact birds. However, there were no differences in lightness, redness, or yellowness values of breast skin measured on the carcass.

Caponization also had a significant effect on muscle colour. The capons were characterized by lighter $\left(\mathrm{L}^{*}\right)$ and more yellow $\left(\mathrm{b}^{*}\right)$ colour and lower redness $\left(\mathrm{a}^{*}\right)$. Our study confirmed the results of other authors (Lin and Hsu, 2003; Sirri et al., 2009; Rikimaru et al., 2009; Symeon et al., 2010). Muscle colour, which depends on the breed, sex, age and physical activity of the birds, is determined mainly by myoglobin and intramuscular fat content. An increase in muscle fat which led to reduction in muscle myoglobin and could reflect major illuminant, resulting in smaller $\mathrm{a}^{*}$ values and greater $\mathrm{L}^{*}$ values, was reported by Troutt et al. (1992) and Lyon and Cason (1995). Our results indicate that both the breast and leg muscles of the capons had higher $(\mathrm{P}>0.05)$ levels of crude fat than the muscles of intact cockerels. Therefore, the decreased $\mathrm{a}^{*}$ value and the increased $\mathrm{L}^{*}$ and $\mathrm{b}^{*}$ values in both muscles and in skin of the capons may be due to the effect of androgens on total lipid content in skin and muscles and to decreased erythropoiesis action (Lin and Hsu, 2003). According to Sirri et al. (2009), capons compared to cockerels had a lower level of total heme pigments. These authors showed a strict positive correlation between total heme pigments concentration and meat redness $\left(\mathrm{a}^{*}\right)$ and a negative correlation between total heme pigments concentration and lightness $\left(\mathrm{L}^{*}\right)$. The myoglobin content of muscles could be attributed to a different oxidative behaviour of muscle fibres, with cocks and capons being the most and the lowest oxidative ones, respectively. It seems that capons have less oxygen necessary for energy metabolism than cocks, because they use lower amounts of it for fighting, courtship behaviour, and protecting territory (Jacob and Mather, 2000). Concentration of myoglobin is responsible for the majority of the red colour and darkness of meat, and exercised muscles are always darker in colour.

The instrumentally assessed breast muscles of the capons were characterized by higher shear force and were tougher than those of cockerels. These findings differ from the majority of the results reported in the literature. According to most researchers, the meat of capons is more tender in organoleptic evaluation and has lower shear 
force when measured instrumentally. It is reported that increase in intramuscular fat is generally associated with decreased shear force values and thus with improved meat tenderness (Symeon et al., 2010). Higher meat tenderness is also favoured by the lower diameter of muscle fibres (Lin and Hsu, 2002), but this was not confirmed by our instrumental measurement. In our study breast muscles from capons, which had a lower diameter of muscle fibres, were tougher. According to Dransfield and Sosnicki (1999), smaller fibre diameters may allow a higher packing density, which increases the toughness of the meat. Smith et al. (1993) report that physicochemical characteristics of bird meat are determined by both the type and diameter of muscle fibres, and their hypertrophy negatively affects the quality of meat (Dransfield and Sosnicki, 1999; Miraglia et al., 2006). However, despite long-term studies concerning the association between the microstructure of chicken muscles and the technological and sensory properties of meat, not all the relationships have been explained. In a study with broiler chickens (Berri et al., 2007), the fibre diameter of $m$. pectoralis superficialis was positively correlated with the weight and yield of breast muscles, but negatively with glycogen levels, thus resulting in higher $\mathrm{pH}$, darker colour and better water holding capacity of the meat. These observations contradict the suggestions of authors who associate poorer meat quality with greater fibre diameter. Also our study did not establish a cause-effect relationship between muscle fibre size and meat quality of castrated and intact chickens. The breast muscles of cockerels from group I, which had a much greater diameter of muscle fibres, were characterized by significantly lower cooking loss compared to capon muscles, but at the same time they did not differ in drip loss. No differences were also observed in the $\mathrm{pH}$ of breast muscles from both groups of birds. The differences in the cooking loss and texture of cooked breast muscles from intact and castrated birds may also result from differences in the other non-analysed factors, such as myofibrillar proteins concentration, distribution and composition of the intramuscular connective tissue, or different thermal characteristics of their muscles (Purslow, 2004; Wattanachant et al., 2005; Chen et al., 2007). In the sensory assessment, however, the meat of capons received slightly higher $(\mathrm{P}>0.05)$ scores for tenderness. The beneficial effect of caponization on meat tenderness is not always confirmed statistically. Muriel Duran (2004) and Symeon et al. (2010) reported only a tendency for more tender breast meat in capons compared with intact cocks. The higher tenderness of meat from capons compared to cockerels is suggested by Lin and Hsu (2002), Rikimaru et al. (2009) and Sirri et al. (2009). However, in contrast to the above results, the earlier studies of the cited authors showed that capon compared to cockerel meat was characterized by significantly lower springiness and cohesiveness, with no differences in toughness (Lin and Hsu, 2002). No effect of caponizing cockerels of different laying lines on shear force values of muscles was reported by Symeon et al. (2012).

The caponization procedure had no effect on the $\mathrm{pH}$ of breast muscles, but significant differences were found between the groups for leg muscles $24 \mathrm{~h}$ postmortem. Our results partly concur with the findings of Lin and Hsu (2002), Miguel et al. (2008) and Volk et al. (2011), which indicate no significant effect of caponization on muscle pH. In turn, Sirri et al. (2009) reported lower pH in the breast muscles of capons, but no differences were found in the $\mathrm{pH}$ of leg muscles. Neither did the same 
authors find any differences in water holding capacity of the muscles. In our study, the breast muscles of capons were characterized by slightly better water holding capacity, but also showed higher thawing loss and cooking loss. The leg muscles of these birds, which showed significantly higher $\mathrm{pH}_{24 \mathrm{~h}}$ value compared to the muscles of cockerels, received higher scores for water holding capacity and were characterized by lower thawing loss and cooking loss.

Similar to the study of Chen et al. (2007), our experiment revealed no significant differences in the nutritive value of breast and leg muscles between capons and cockerels. The lack of differences in the level of crude protein in the muscles from the analysed bird groups is indicative that caponization does not alter the synthesis of this component in castrated male chickens. Compared to cockerels, capons showed a tendency for higher fat content, especially in leg muscles. Higher lipid and cholesterol concentration in capon muscles was also reported by Sirri et al. (2009). Many authors stress that higher fat accumulation in muscles contributes to improving the sensory parameters (Miguel et al., 2008; Lin et al., 2011; Lin and Hsu, 2013). Such meat is characterized by higher palatability, juiciness and tenderness, which makes it more attractive; this was also observed in our study. In the sensory assessment, the tasters gave consistently higher scores to the meat of capons, in particular the fat-rich leg muscles, which received higher scores for juiciness, tenderness and flavour.

The results of our study indicate that the caponization of Greenleg Partridge cockerels increases body weight, dressing percentage and carcass muscling, changes some muscle physicochemical parameters, while improving the sensory appeal of the meat. This enables redundant male chicks to be used as a valuable material for production of high quality poultry meat.

\section{References}

Baryłko-Pikielna N., Matuszewska I. (2009). Sensory testing of food (in Polish). Wyd. Nauk. PTTZ, 367 pp.

Berri C., Le Bihan-Duval E., Debut M., Santé-Lhoutellier V., Baéza E., Gig a u d V., J é g o Y., D u c l o s M.J. (2007). Consequence of hypertrophy on characteristics of pectoralis major muscle and breast meat quality of broiler chickens. J. Anim. Sci., 85: 2005-2011.

Calik J. (2014). Capon production - breeding stock, rooster castration, rearing methods, and meat quality. Ann. Anim. Sci., 14: 769-777.

C a s o n J.A., F l e t c h e r D.L., B u r k e W.H. (1987). Influence of caponization on skin pigmentation of male broilers. Poultry Sci., 66: 433-438.

Ch e n K.L., Ch i W.T., Ch i o u P.W.S. (2005). Caponization and testosterone implantation effects on blood lipid and lipoprotein profile in male chickens. Poultry Sci., 84: 547-552.

Chen K.L., H s i eh T.Y., Chi ou P.W.S. (2006). Caponization effects on growth performance and lipid metabolism in Taiwan country chicken cockerels. Asian-Aust. J. Anim. Sci., 19: 438-443.

Che n K.L., Chen T.T., L in K.J., C h i o u P.W.S. (2007). The effect of caponization age on muscle characteristics in male chicken. Asian-Aust. J. Anim. Sci., 20: 1684-1688.

Commission Regulation (EC) No 543/2008 of 16 June 2008 laying down detailed rules for the application of Council Regulation (EC) No 1234/2007 as regards the marketing standards for poultry meat.

Dransfield E., S os nicki A.A. (1999). Relationship between muscle growth and poultry meat quality. Poultry Sci., 78: 743-746. 
Gra u R., H a m m R. (1953). Eine Einfache Methode zur Bestimmung der Wasserbindung im Muskel. Naturwiss, 40: 29-30.

J a c o b J., M a the r F.B. (2000). Capons. Factsheet PS-54, Department of Animal Sciences, Florida Cooperative Extension Service, Institute of Food and Agricultural Sciences, University of Florida, Gainesville. www.edis.ufl.edu.

K r a w c z y k J., S o k o ł o w i c z Z., S z y m c z y k B. (2011). Effect of housing system on cholesterol, vitamin and fatty acid content of yolk and physical characteristics of eggs from Polish native hens. Archiv für Geflügelkunde, 75: 151-157

L in C.Y., H s u J.C. (2002). Effect of surgical caponization on growth performance, fiber diameter and some physical properties of muscles in Taiwan country chicken cockerels. Asian-Aust. J. Anim. Sci., 15: 401-405.

L in C.Y., H s u J.C. (2003). Influence of caponization on the carcass characteristics in Taiwan country chicken cockerels. Asian-Aust. J. Anim. Sci., 16: 575-580.

L i n C.Y., H s u J.C. (2013). Comparison of skin and muscle color, muscle composition and sensory panel score of capon, slip and intact birds in Taiwan country chicken cockerels. J. Taiwan Livest. Res., 46: 187-194.

L in C.Y., L i n L.C., H s u J.C. (2011). Effect of caponization on muscle composition, shear value, ATP related compounds and taste appraisal in Taiwan country chicken cockerels. Asian-Aust. J. Anim. Sci., 24: 1026-1030.

L y o n C.E., C a s o n J.A. (1995). Effect of water chilling on objective color of bruised and unbruised broiler tissue. Poultry Sci., 74: 1894-1899.

Mahmud M.A., Shaba P., Gana J., Yis a H.Y., Ndagimba R. (2013). Effects of surgical caponisation on growth, carcass and some hematological parameters in cockerel chickens. Sokoto J. Vet. Sci., 11: 57-62.

Migue l J.A., Ciri a J., A s e n j o B., C a lv o J.L. (2008). Effect of caponization on growth and on carcass and meat characteristics in Castellana Negra native Spanish chickens. Animal, 2: 305-311.

Miraglia D., Mammoli R., Branciari R., Ranucci D., Cenci Goga B.T. (2006). Characterization of muscle fibre type and evaluation of the presence of giant fibres in two meat chicken hybrids. Vet. Res. Comm., 30 (Suppl. 1): 357-367.

Muriel Duran A. (2004). The effect of caponization on production indices and carcass and meat characteristics in free-range Extremeña Azul chickens. Span. J. Agric. Res., 2: 211-216.

Połtowicz K., Wężyk S., Ca lik J., Paściak P. (2004). The use of native chicken breed in poultry meat production. Proc. Brit. Soc. Anim. Sci., 1: 30-32.

Purs low P.P. (2004). Intramuscular connective tissue and its role in meat quality. Meat Sci., 70: 435-447.

Rahman M.M., I s 1 a m M.A., A 1 i M.Y., Khondaker M.E.A., Hossain M.M. (2004). Effect of caponization on body weight, hematological traits and blood cholesterol concentration of Nara chicken. Int. J. Poult. Sci., 3: 284-286.

Rikimaru K., Shiji O., Komastu M., Ishizuka J. (2009). Effects of caponization on meat quality of Hinai-jidori chicken. J. Poult. Sci., 46: 345-350.

Sh a o Y., Wu C., Li J., Zh a o C. (2009). The effect of different caponization age on growth performance and blood parameters in male Tibetan chicken. Asian J. Anim. Sci., 4: 228-236.

Sinanoglou V.J., Mant is F., Miniadis-Meimaroglou S., Symeon G.K., Bize1 is I.A. (2011). Effects of caponisation on lipid and fatty acid composition of intramuscular and abdominal fat of medium-growth broilers. Br. Poultry Sci., 52: 310-317.

Sirri F., Bianchi M., Petracci M., Meluzzi A. (2009). Influence of partial and complete caponization on chicken meat quality. Poultry Sci., 88: 1466-1473.

S m it h D.P., F le t c her D.L., B u hr R.J., B e y e r R.S. (1993). Pekin duckling and broiler chicken pectoralis muscle structure and composition. Poultry Sci. 72: 202-208.

Symeon G.K., Mantis F., Bizelis I., Kominakis A., Rogdakis E. (2010). Effects of caponization on growth performance, carcass composition, and meat quality of medium growth broiler. Poultry Sci., 89: 1481-1489.

Symeon G.K., Mantis F., Bizelis I., Kominakis A., Rogdakis E. (2012). Effects of caponization on growth performance, carcass composition and meat quality of males of a layer line. Animal, 6: 2023-2030. 
Tor M., Estany J., Villalba D., Molina E., Cubilò M.D. (2002). Comparison of carcass composition by parts and tissues between cocks and capons. Anim. Res., 51: 421-443.

Tor M., Es t a n y J., Fra n c e s ch D.A., C u bil ò M.D. (2005). Comparison of fatty acid profiles of edible meat, adipose tissues and muscles between cocks and capons. Anim. Res., 54: 413-424.

Troutt E.S., Hunt M.C., Johnson D.E., Claus J.R., Ka s tner C.L., Kropf D.H., Strod a S. (1992). Chemical, physical and sensory characterization of ground beef containing 5 to 30 percent fat. J. Food. Sci., 57: 25-29.

Volk M., Malenšek J., Prevolnik M., Škrlep M., Š e gula B. Čandek-P otokar M., B a ve c M. (2011). Differences in carcass and meat quality between organically reared cocks and capons. Agric. Conspec. Sci., 76: 153-155.

Watt a n a ch an t S., B e n j a ku 1 S., L e d w ard D.A. (2005). Microstructure and thermal characteristics of Thai indigenous and broiler chicken muscles. Poultry Sci., 84: 328-336.

Zi ołecki J., Doruchowski W. (1989). Evaluation methods of slaughter value (in Polish). COBRD Poznań, Poland, pp. 1-22.

Received: 11 VII 2014

Accepted: 25 XI 2014 